p-ISSN : 2541-6782, e-ISSN : 2580-6467

\title{
IMPLEMENTASI PROGRAM PENDIDIKAN KARAKTER DAN PROGRAM GERAKAN LITERASI SEKOLAH DALAM MEMBENTUK SIKAP KEMANDIRIAN BELAJAR SISWA DI SDN PERCOBAAN 2 DAN SD MUHAMMADIYAH SAPEN
}

\author{
Anis Rofiah \\ Program Pasca Sarjana \\ Universitas Muhammadiyah Yogyakarta \\ E-mail: anis.rofiah08@gmail.com
}

\begin{abstract}
Abstrak
Penelitian ini bertujuan untuk mengetahui: (1) rancangan program pendidikan karakter dan Gerakan Literasi dalam membentuk karakter kemandirian belajar siswa: (3) penilaian orang tua dan siswa terhadap kedua program tersebut; (3) perubahan tingkah laku kemandirian belajar siswa kelas 4 sebagai hasil dari pelaksanaan kedua program tersebut; dan (4) kemandirian belajar siswa yang terinternalisasi pada diri siswa. Metode penelitian adalah kualitatif dan kuantitatif. Populasi penelitian ini adalah Kepala Sekolah, guru kelas 4 dan seluruh siswa kelas 4 SDN Percobaan 2 dan SD Muhammadiyah Sapen dengan sampel sejumlah 141 siswa. Hasil dari penelitian ini: (1) Optimalisasi pendidikan karakter, baik SD Muhammadiyah Sapen maupun di SD Negeri Percobaan 2 Yogyakarta dilaksanakan dengan strategi pemberian reward dan punishment dan terbukti memberikan hasil yang baik dengan perolehan prestasi; (2) orang tua dan siswa menilai kedua program tersebut positif dan mendukungnya; (3) kemandirian belajar siswa kelas 4 di SD Negeri Percobaan 2 Yogyakarta dan SD Muhammadiyah Sapen berada pada kategori sangat mandiri; dan (4) Keteladanan dan pembiasaan dalam program pendidikan karakter dan gerakan literasi di SD Negeri Percobaan 2 Yogyakarta dan SD Muhammadiyah Sapen membawa dampak kemandirian belajar siswa.
\end{abstract}

Kata kunci: program pendidikan karakter, gerakan literasi, sikap, kemandirian belajar

\begin{abstract}
This study aims to determine: (1) the design of character education programs and the Literacy Movement in shaping the character of student learning independence: (3) parents and students' assessment of the two programs; (3) changes in class 4 students' independence of learning behavior as a result of implementing the two programs; and (4) student learning independence internalized in students. The research methods are qualitative and quantitative. The population of this study was the Principal, 4th grade teacher and all 4th grade students of SDN Experiment 2 and SD Muhammadiyah Sapen with a sample of 141 students. The results of this study: (1) Optimizing character education, both Muhammadiyah Sapen Elementary School and SD Negeri Experiment 2 Yogyakarta carried out with a strategy of giving reward and punishment and proven to provide good results with achievement; (2) parents and students rate both programs positively and support them; (3) learning independence of 4th grade students in SD Negeri Experiment 2 Yogyakarta and Muhammadiyah Sapen Elementary School are in the very independent category; and (4) Exemplary and habituation in the character education program and literacy movement at SD Negeri Experiment 2 Yogyakarta and SD Muhammadiyah Sapen bring the impact of student learning independence.
\end{abstract}

Keywords: character education programs, literacy movements, attitudes, learning independence

\section{Info Artikel}

Diterima Januari 2019, disetujui Februari 2019, diterbitkan Juni 2019 


\section{PENDAHULUAN}

Pemerintah Indonesia melalui Kementerian Pendidikan Nasional mencanangkan penerapan pendidikan karakter bagi semua tingkat pendidikan sejak tahun 2010, baik sekolah dasar hingga perguruan tinggi. Program pendidikan karakter dalam dunia pendidikan digagas karena selama ini proses pendidikan ternyata belum berhasil membangun manusia yang berkarakter. Dalam hal ini Asmani juga berpendapat bahwa selama ini sekolah hanya berkutat dengan target-target akademik dan melupakan karakter. Program Pendidikan Karakter diperkuat dengan permen Dikbud No.23 tahun 2015, yaitu tentang Gerakan Literasi sekolah. Dalam sambutannya bapak Hamid Muhammad selaku Dirjen Pendidikan Dasar dan Menengah mengatakan bahwa panduan program ini salah satu tujuan utamanya adalah memperkuat penumbuhan "Budi Pekerti".

Salah satu dari tujuan program Pendidikan Karakter dan Gerakan Literasi sekolah adalah karakter mandiri. Pengertian mandiri juga sama dengan pengertian budi pekerti yang secara subtansi juga memacu keberanian seseorang untuk berbuat atau bereaksi, tidak pasrah dan beku, tetap dinamis, energik dan selalu optimis menuju masa depan. Karakter kemandirian menjadi salah satu tujuan utama baik dalam program Pendidikan Karakter maupun program Gerakan Literasi sekolah. Untuk itulah Kementerian Pendidikan Nasional melakukan revitalisasi pendidikan karakter dalam rangka membangun karakter bangsa Indonesia. Karakter yang akan dibangun tidak hanya karakter kesantunan, tetapi juga karakter yang mampu menumbuhkan "Kepenasaran Intelektual" sebagai modal untuk membangun kreatifitas, daya inovasi dan kemandirian ilmiah.

Program Gerakan Literasi Sekolah juga bertujuan membentuk karakter kemandirian sebagaimana hal ini tertuang dalam tujuan umum Gerakan Literasi Sekolah, yaitu Menumbuh kembangkan budi pekerti peserta didik melalui pembudayaan ekosistem literasi sekolah yang diwujudkan dalam Gerakan Literasi Sekolah agar mereka menjadi pembelajar sepanjang hayat. Rendahnya karakter kemandirian belajar pada siswa kelas 4 di SDN Percobaan 2 dan SD Muhammadiyah Sapen merupakan salah satu masalah yang harus segera dicari solusinya, jika siswa tidak memiliki kemandirian belajar maka akan berpengaruh terhadap motivasi untuk meraih tujuan yaitu, prestasi belajar yang memuaskan. Sebagaimana hal ini dikuatkan 
oleh Butler, yang dikutip oleh Utari Sumarmo bahwa Self Regulated Learning atau kemandirian belajar merupakan siklus kegiatan kognitif yang recursive (berulang-ulang) yang memuat kegiatan: menganalisis tugas; memilih, mengadopsi, atau menemukan pendekatan strategi untuk mencapai tujuan tugas; dan memantau hasil dari strategi yang telah dilaksanakan.

Pada realitasnya siswa kelas 4 pada SDN Percobaan 2 dan siswa kelas 4 pada SD Muh Sapen secara umum masih banyak yang belum mandiri belajar, selain faktor usia juga karena pola asuh orang tua di rumah yang kurang memberikan kesempatan kepada anak untuk mandiri. Masih sedikit anak yang secara sadar memperluas pengetahuan dengan pergi ke perpustakaan ataupun mengulang pelajaran, kecuali jika ada PR dari gurunya.

SDN Percobaan 2 adalah salah satu SD yang mendapatkan MOU pada tahun 2012 di Bandung untuk menjadi piloting project program Pendidikan Karakter dengan mendapatkan bantuan dana dari pemerintah sebesar 30 juta. Sekaligus Sekolah ini juga sudah melaksanakan Program Gerakan Literasi Sekolah sejak tahun 2016. Begitu juga sebagai salah satu sekolah favorit di Kota Yogyakarta, SD Muhammadiyah Sapen telah meraih lomba sekolah Pendidikan Karakter pada tahun 2013 dan telah melaksanakan program GLS juga. Setelah peneliti melakukan wawancara dengan guru ataupun kepala sekolah dari ke-2 SD diatas diantara persoalan yang utama dari karakter siswa adalah kemandirian belajar, karakter ini juga merupakan salah satu tujuan utama dilaksanakan program Pendidikan karakter dan Gerakan Literasi sekolah.

\section{Pengertian Kemandirian}

Pengertian mandiri jika dapat ditinjau dari dua segi, yaitu pengertian secara etimologi (bahasa) dan pengertian secara terminologi (istilah). Kemandirian diartikan oleh Herman Holstein sebagai sikap mandiri yang inisiatifnya sendiri mendesak jauh ke belakang setiap pengendalian asing yang membangkitkan swakarsa tanpa perantara dan secara spontanitas yakni ada kebebasan bagi keputusan, penilaian, pendapat, pertanggung jawaban tanpa menggantungkan orang lain. Drost menjelaskan kemandirian (kematangan pribadi) sebagai keadaan kesempurnaan dan keutuhan kedua unsur (budi dan akal) dalam kesatuan pribadi. 
Enung Fatimah mendefinisikan mandiri (berdiri diatas kaki sendiri dengan kemampuan seseorang untuk tidak bergantung dengan orang lain serta bertanggung jawab atas apa yang dilakukannya. Sedangkan Zakiyah Daradjat menjelaskan mandiri adalah: Kecenderungan anak untuk melakukan sesuatu yang diinginkannya tanpa minta tolong kepada orang lain. Juga mengukur kemampuannya untuk mengarahkan kelakuannya tanpa tunduk kepada orang lain. Biasanya anak yang berdiri sendiri lebih mampu memikul tanggungjawab, dan pada umumnya mempunyai emosi yang stabil.

Dari uraian di atas dapat disimpulkan kemandirian belajar adalah suatu perubahan dalam diri seseorang yang merupakan hasil dari pengalaman dan latihan diri sendiri tanpa bergantung pada orang lain. Dalam bertingkah laku mempunyai kebebasan membuat keputusan, penilaian pendapat serta bertanggung jawab tanpa menggantungkan kepada orang lain.

\section{Pengertian Program Pendidikan Karakter}

Pendidikan karakter berpusat pada satuan pendidikan yang merupakan sarana utama yang secara optimal memanfaatkan dan memberdayakan semua lingkungan belajar yang ada untuk memperbaiki menguatkan dan menyempurnakan secara terusmenerus proses Pendidikan Karakter di sekolah. Pendidikan menjadi ujung tombak dalam upaya pengembangan karakter manusia yang bermartabat.

Pelaksanaan pendidikan karakter di Sekolah Dasar adalah sebagai berikut:

a. Pelaksanaan kegiatan belajar-mengajar dengan mengintegrasikan dalam kegiatan belajar-mengajar melalui berbagai mata pelajaran yang ada di sekolah dasar.

b. Pelaksanaan kegiatan pembiasaan keseharian yang ada berada di sekolah dasar, melalui pengembangan budaya/kultur sekolah untuk pengembangan pendidikan karakter.

c. Pelaksanaan ekstrakurikuler seperti olahraga, pramuka, pembiasaan kehidupan keseharian di rumah yang selaras dengan kehidupan di sekolah dasar.

\section{Pengertian Program Gerakan Literasi Sekolah}

GLS merupakan suatu usaha atau kegiatan yang bersifat partisipatif dengan melibatkan warga sekolah (peserta didik, guru, kepala sekolah, tenaga kependidikan, pengawas sekolah, Komite Sekolah, orang tua/wali murid peserta didik), akademisi, 
penerbit, media massa, masyarakat (tokoh masyarakat yang dapat merepresentasikan keteladanan, dunia usaha, dll.), dan pemangku kepentingan di bawah koordinasi Direktorat Jenderal Pendidikan Dasar dan Menengah Kementerian Pendidikan dan Kebudayaan.

\section{METODE PENELITIAN}

Jenis penelitihan ini adalah penelitihan deskriptif dengan pendekatan kualitatif dan kuantitatif. Populasi penelitian ini adalah Kepala Sekolah, guru kelas 4 dan seluruh siswa kelas 4 SDN Percobaan 2 dan SD Muhammadiyah Sapen. Populasi siswa kedua sekolah tersebut berjumlah 213 siswa, dan sebagai sampel penelitian 65\% atau sejumlah 141 siswa. Data diambil dengan dokumentasi, wawancara dan angket.

\section{HASIL DAN PEMBAHASAN}

Implementasi program pendidikan karakter di sekolah SDN Percobaan 2 dan SD Muhammadiyah Sapen diintregasikan dalam pembelajaran, pengembangan minat atau ekstrakurikuler dan penciptaan budaya sekolah. Berdasarkan hasil wawancara dengan kepala sekolah dan beberapa guru kelas 4 berikut beberapa program sekolah yang berkaitan dengan impementasi Program Pendidikan Karakter budaya senyum sapa dan salam, peduli lingkungan, penanaman karakter kebangsan melalui upacara bendera, dan mengasah kepedulian sosial melalui kerja bakti, qurban di hari raya idul Adkha serata gerakan infak. Sedangakan implementasi Program gerakan Literasi sekolah (GLS) di kedua sekolah tersebut, yaitu Literasi dasar yang meliputi pembiasaan, pembelajaran dan pengayaan. Program tersebut diimplementasikan 15 menit sebelum pembelajaran. Di SDN Percobaan 2 secara spesifik mempunyai program Seyum Literasi (Gerakan menyisihkan uang saku untuk membeli buku) dan Shadaqah buku setiap bulan. Sedangkan Di Sd Muhammadiyah sapen GLS banyak difasilitasi oleh Perpustakan dengan programnya Gebyar Literasi, yaitu lomba dongeng, lomba baca puisi, lomba cipta puisi \& pantun, lomba cerpen, lomba mading, lomba cerita bergambar, lomba artikel ilmiah sederhana, dan lomba perpustakaan kelas. 
Tingkat Kemandirian Belajar Siswa Setelah Mengikuti Program Pendidkan Karakter dan Program Gerakan Literasi Sekolah

\section{Analisis Statistik Deskriptif}

Karakter kemandirian belajar siswa sebagai hasil dari pelaksanaan program pendidikan karakter dan program gerakan literasi pada penelitian ini diukur dengan 14 item pernyataan, dengan skala likert 1 sampai dengan 5, sehingga diperoleh rentangan skor antara 14 sampai dengan 70. Berdasarkan analisis data dengan bantuan software komputer, diperoleh rerata (mean) kemandirian belajar siswa sebesar 59,88; median= 60,$00 ;$ modus $=60,00$ dan standart deviasi sebesar $=5,164$. Skor rerata tersebut berada pada interval kelas 48 s.d. 59 kategori sangat mandiri. Dengan demikian dapat dikatakan bahwa kemandirian belajar sebagai hasil dari pelaksanaan program pendidikan karakter dan program gerakan literasi sekolah di SD Percobaan 2 Yogyakarta dan Muhammadiyah Sapen berada pada kategori sangat mandiri.

Kemandirian belajar sebagai hasil dari pelaksanaan program pendidikan karakter dan program gerakan literasi sekolah di SD Percobaan 2 Yogyakarta dan Muhammadiyah Sapen berdasarkan pengkategoriannya dapat dilihat pada tabel berikut ini.

Tabel 1. Distribusi Frekuensi Kemandirian Belajar

\begin{tabular}{|l|l|l|l|l|}
\hline \multirow{2}{*}{ No. } & \multirow{2}{*}{$\begin{array}{l}\text { Interval } \\
\text { Skor }\end{array}$} & Kategori & \multicolumn{2}{|l|}{ Frekuensi } \\
\cline { 4 - 5 } & & $\mathrm{N}$ & $\begin{array}{l}\text { Persentase } \\
(\%)\end{array}$ \\
\hline 1. & $60-70$ & Sangat Mandiri & 76 & 53,9 \\
2. & $48-59$ & Mandiri & 65 & 46,1 \\
3. & $36-47$ & Kurang Mandiri & 0 & 0,0 \\
4. & $25-35$ & Tidak Mandiri & 0 & 0,0 \\
5. & $14-24$ & Sangat Tidak Mandiri & 0 & 0,0 \\
\hline
\end{tabular}


Dari tabel distribusi frekuensi kemandirian belajar sebagai hasil dari pelaksanaan program pendidikan karakter dan program gerakan literasi sekolah di SD Percobaan 2 Yogyakarta dan Muhammadiyah Sapen, secara visual dapat disajikan dalam bentuk diagram lingkarannya sebagai berikut:

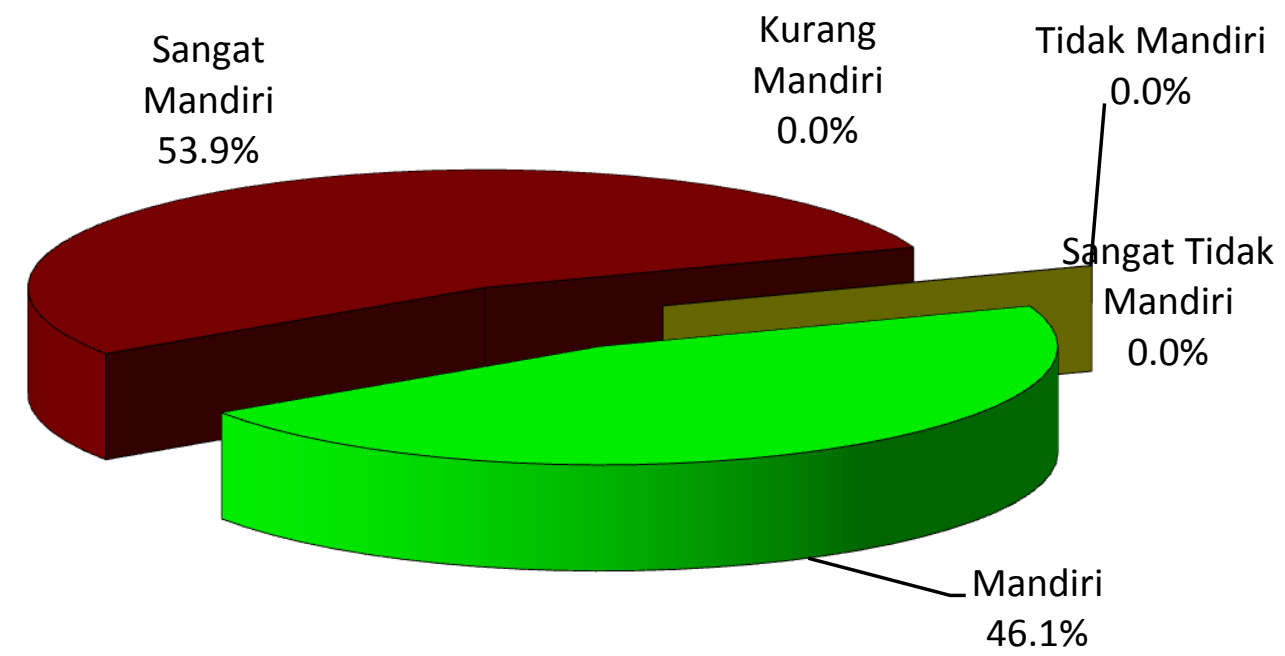

Gambar 1. Kemandirian Belajar Siswa

Tabel dan histogram di atas, memperlihatkan bahwa dari 141 orang siswa peserta program pendidikan karakter dan program gerakan literasi sekolah di SD Percobaan 2 Yogyakarta dan Muhammadiyah Sapen; 53,9\% siswa sangat mandiri dan 46,1\% mandiri; tidak ada siswa yang berada pada kategori kurang mandiri, tidak mandiri dan sangat tidak mandiri.

Karakter kemandirian pada pendidikan karakter dan program gerakan literasi sekolah di SD Percobaan 2 Yogyakarta dan Muhammadiyah Sapen pada penelitian ini, terdiri dari lima faktor, yaitu: (1) mampu mengambil inisiatif, (2) mampu mengatasi masalah, (3) penuh ketekunan, (4) memperoleh kepuasan dari hasil usahanya; dan (5) berkeinginan mengerjakan sesuatu tanpa bantuan orang lain. Analisis pada tiap faktor dan item pernyataan tersebut disajikan pada tabel berikut ini. 


\section{KESIMPULAN}

Berdasarkan hasil penelitian dan pembahasan, dapat disimpulkan hal-hal sebagai berikut

1. Rancangan program pendidikan karakter dan gerakan literasi dalam membentuk karakter kemandirian belajar siswa kelas 4 di SD Negeri Percobaan 2 Yogyakarta dan SD Muhammadiyah SapenOptimalisasi pendidikan karakter, baik SD Muhammadiyah Sapen maupun di SD Negeri Percobaan 2 Yogyakarta dilaksanakan dengan diantaranya denagn strategi pemberian reward dan punishment serta sinergi antara pihak sekolah dengan komite yang sangat baik, terbukti memberikan hasil yang baik dengan perolehan prestasi di tingkat nasional maupun internasional, kualitas lulusan yang handal, dan lingkungan sekolah yang representatif dan kondusif. Hasil dari penerapan pendidikan karakter sekolah di SD Muhammadiyah Sapen Yogyakarta maupun di SD Negeri Percobaan 2 Yogyakarta adalah: terciptanya lingkungan sekolah yang kondusif, sebagian besar siswa datang tepat waktu, siswa melakukan ucap salam dan jabat tangan setiap bertemu siapa saja, berkurangnya anak yang sakit di UKS, meningkatnya kebutuhan minat baca siswa di perpustakaan, siswa terbiasa hidup bersih dan sehat, kebiasaan membuang sampah pada tempatnya, dan siswa terbiasa memilih jajanan yang sehat. Hasil tersebut memberikan kontribusi terhadap kemandirian siswa dalam belajarnya, siswa lebih percaya diri, tidak mencontek, tidak berbuat curang, dan bertanggungjawab.

2. Berdasarkan hasil angket siswa, disimpulkan bahwa kemandirian belajar siswa kelas 4 di SD Negeri Percobaan 2 Yogyakarta dan SD Muhammadiyah Sapen berada pada kategori sangat mandiri. Dari 141 siswa; 53,9\% siswa sangat mandiri dan 46,1\% mandiri; tidak ada siswa yang berada pada kategori kurang mandiri, tidak mandiri dan sangat tidak mandiri.

\section{DAFTAR PUSTAKA}

Akbar Sa'adun dkk. 2011. Gran Design Revitalisasi Pendidikan Karakter Di Sekolah Dasar Melalui Pendekatan Menyeluruh. Jakarta: Direktorat Jenderal Pendidikan Dasar Kementerian Pendidikan dan Kebudayaan.

Enung Fatimah.2006. Psikologi Perkembangan: Perkembangan Peserta Didik, Bandung: Pustaka Setia. 
http://6it.lvl20TjRt tanggal 27 Februari 2017.jam 13.00

http://dikdasmen.kemendikbud.go.id/index.php.laporan-gls-semester-tahun-2016.

Herman Holstein. 1986. Murid Belajar Mandiri. Bandung: Remaja Rosdakarya.

J.I.G. Drost. 2004. Sekolah Mengajar atau Mendidik? Yogyakarta: Kanisius.

Pangesti Widarti dkk.2016. Desain Induk Gerakan Literasi Sekolah, Jakarta: Dirjen Dikdasmen Kementerian Pendidikan dan Kebudayaan.

Sugiono, 2003.Metode Penelitihan Bisnis.Bandung : Pusat Bahasa Depdiknas.

Suharsimi Arikunto \& Jabar, S.A. 2010. Evaluasi Program Pendidikan: Pedoman ProsedurPenelitian: Suatu Pendekatan Praktik (Edisi Revisi VI). Jakarta: Rineka Cipta.

Suparman Sumahamijaya et.all.2003. Pendidikan Karakter Mandiri Dan Kewiraswastaan. Bandung: Angkasa.

Zakiah Darajat. Ilmu Jiwa Agama. 1993 Jakarta: Bulan Bintang, 1993 